\title{
Innovation Measures to Promote the Outstanding National Dance Culture Going out under the "One Belt and One Road" Strategy
}

\author{
Chi Zhang ${ }^{1, a}$, Xiaojie Wang ${ }^{2, b}$ \\ ${ }^{1}$ School of Education and Sports, Bohai University, Jinzhou, 121013, China \\ ${ }^{2}$ College of Art and Communication, Bohai University, Jinzhou, 121013, China \\ a378290420@qq.com, b1019813588@qq.com
}

Keywords: One Belt And One Road, national dance, cultural going out, innovation measures

\begin{abstract}
Ethnic dance is a common platform for people to build the "One Belt and One Road", and encourages the countries along the "Belt and Road" to actively participate in cultural exchanges and cooperation, carry forward the spirit of the Silk Road, promote the "going global" of Chinese culture and expand the international influence of an outstanding ethnic dance culture force. Based on the relevant theories and references, this paper puts forward some innovative measures to promote the outstanding national dance culture through the "Belt and Road" strategy: establishing a Chinese cultural communication system, giving play to the role of new media technologies, paying attention to the top-level design of dance culture communication, focusing on The combination of national aesthetic and human nature, the reform of college dance professionals training mode, to build inclusive and harmonious global vision, enhance the competitiveness of cultural enterprises, and fully tap the characteristics of ethnic dance resources.
\end{abstract}

\section{Introduction}

The proposed "Belt and Road" strategy is an objective need for China to further integrate itself into the world economic system and strengthen economic, trade and cultural cooperation with its neighboring countries. It is a major policy decision that will influence and optimize the order and pattern of world economic and social development. Promoting the going of Chinese culture is an important part of the "Belt and Road" strategy. It is necessary to reflect on the relevant issues of "promoting the going of Chinese culture in the implementation of the" Belt and Road "strategy. The "Belt and Road Initiative" is not only an economic strategy and a diplomatic strategy for our country's opening to the outside world, but also an important cultural strategy for realizing the going out of Chinese culture. Through the implementation of this strategy, we will further deepen cultural exchanges and trade with countries along the line, promote regional cooperation and long-term development so that all countries along the line can absorb and integrate the reasonable content of foreign cultures and promote the common development and common prosperity of civilizations.

Chinese ethnic minority dance is an important part of the Chinese minority culture. The ethnic dance culture in this subject refers to the dance of Chinese minorities. Guided by the relevant theories of cultural communication, the paper comprehensively uses various methods such as literature research, field investigation, field observation, reliability analysis and comparative study to follow the strategy of "One Belt and One Road" to promote the excellent national dance culture , Put forward the innovative measures of "Belt and Road" strategy to promote the excellent national dance culture and provide practical solutions for the outstanding national dance culture to go global.

\section{Realistic Meaning}

In the long history of our country, all ethnic groups formed a dance culture with unique national characteristics. The reason why the national dance culture is loved by the majority of the people is that people express their aspirations and their desire and pursuit for a better life so that they can 
enjoy physical and mental pleasure in the national dance culture. But the world is evolving and people's needs are constantly changing. If the national dance culture needs to be developed better, it needs to recognize people's needs and keep making progress to meet people's needs. With ethnic dance as a carrier, it has fully exerted its artistic function. However, while continuing to dig deeper into the national dance culture, we must also pay attention to keeping pace with the times, continue to innovate, and be better developed in a rapidly changing world. Therefore, it is necessary to inherit and carry forward the national dance culture, let the national dance culture be further popular, promote the national dance culture to go out and make the outstanding national culture shine.

(1) Outstanding national dance culture is the inherent requirement of expanding the living space of our national culture. Culture going global is an inevitable requirement for cultural survival and an inevitable measure for expanding the living space of national culture. Chinese culture should go abroad and take the initiative to devote itself to the trend of world cultural development and competition in an open manner. It should also carry forward the fine tradition of national culture, draw on the strengths of all ethnic groups in the world, make innovations in contents and forms, and constantly enhance the vitality and charisma of the socialist culture with Chinese characteristics. In the tradition of inheritance, the ancient Chinese civilization has gained new vitality in the ups and downs of the world culture, created people's favorite and cultural products, and expanded the space for the survival of ethnic dance culture.

(2) Outstanding national dance culture is an objective need to revitalize our national culture industry. The strategy of cultural going-out is one of the most prominent topics concerning cultural development in our country in recent years. It is put forward in the face of the cultural industry's in-depth participation in the competition of international cultural industries and the international cultural market ${ }^{[1]}$. On the one hand, it is an inevitable extension of the "going out" of China's economy in the field of cultural industry development, and it is also the inevitable result of the opening of China's cultural market to the outside world. The deeper reason is to overcome China's situation of passive beating of the cultural industry after the opening-up to all parts of the world and to take the initiative to tackle the problem by actively expanding international cultural trade, overcoming the huge cultural trade deficit and safeguarding the national cultural security.

\section{Follow the Principles}

The strategy of "Belt and Road" to promote the excellent national dance culture needs to follow the following principles:

(1) Let it be. Cultural dissemination is a natural and gradual process. The flourishing of the country and the influence of culture go hand in hand, and no quick success ${ }^{[2,3]}$. Do not go out of culture deliberately pursue the results, as long as the country maintained its strong momentum, the international spread of ethnic dance culture and influence will be a qualitative leap. As the national dance culture goes global, it is only necessary to show the core of national dance in a form acceptable to the countries along the Belt and Road, instead of copying the national dance as a whole.

(2) Relying on economic and trade. The strategy of "One Belt and One Road" takes the economic and trade exchange activities as the carrier, carries forward the Silk Road culture, spreads the Chinese voice and displays the Chinese brand image. Cultural communication has never been isolated social behavior, but attached to other carriers such as business contacts. National dance culture to go out, can not rely on free appreciation, we must create more world-class quality products, products in the culture, pass in the business spirit.

(3) Based on the private sector. The root and soul of the outstanding national dance culture are deeply rooted in the masses of the people. Without the extensive participation of the people, the communication of the outside world loses its significance. Therefore, it is necessary to reduce government participation, dilute the official color, fully exploit the potential of Chinese non-governmental organizations and overseas Chinese and ethnic minorities, and allow private forces and talents to fully release their energy in international competition. They should seize new opportunities in the "Belt and Road Initiative" and bring the excellent Chinese national dance 
Culture spread further.

(4) Reflect respect. Every national culture is worth looking into and respected. The evolution of world civilization is not the result of a one-man show of a major power, a total of hundreds of different kinds of culture. The broad and profound Chinese culture must show its full flavor and style, respect the traditional culture of the countries along the Belt and Road, and stick to the principle of "going out" and "inviting in" to avoid the unilateral strong export of Chinese culture.

\section{Innovation Measures}

Initiatives refer to actions or behaviors and are the best arrangements and concrete implementation of important work for the future. The national dance culture has the universality of traditional culture and its own particularity. Therefore, it is necessary to draw lessons from the experience of traditional culture going abroad and make measures to adapt to its particularity. This needs to be done in many aspects to be effective and requires a comprehensive analysis of various factors. This is a complicated and systematic task. Based on the relevant theories and with reference to the relevant literature, the innovative measures proposed by the "One Belt and One Road" proposed in this paper to promote a good national dance culture are as follows:

(1) Construction of Chinese culture communication system ${ }^{[4,5]}$. The construction of a cultural and communication system is conducive to mutual understanding and coordinated development in different regions. It has provided the international community with a peaceful and stable environment and facilitated the trade exchanges between the countries of the Belt and Road so as to make the countries in the region closer together. The "One Belt and One Road" strategy has provided a new platform and opportunity for the establishment of China's cultural transmission system. There are many complicated situations along the line of the "One Belt and One Road", such as the wider audience and the fragmented and independent cultural concepts of various countries. As a result, the difficulty of cultural communication has been raised and it becomes a major challenge to construct a systematic cultural communication system. The construction of cultural transmission system needs to identify the cultural orientation, enrich the cultural contents, enrich the media and create a good social and cultural environment.

(2) Play a new media technology role ${ }^{[6]}$. The new media is a medium that uses digital and Internet technologies to provide information and services to the public through terminals such as the Internet, broadband LAN, wireless communication networks and satellites, as well as computers, cell phones and digital television sets. Dance and a variety of new media technologies combine to create a strong impetus to dance development. The speed and breadth of television dance, multimedia dance, holographic dance and digital dance spread far beyond the traditional stage performance forms, bringing unlimited possibilities to the existence of dance and promoting the development and innovation of stage dance. During the process of going out, the outstanding national dance culture must give full play to the role of new media technologies and give full play to its advantages of large capacity, strong interaction and rapid propagation so as to be easily accepted by the countries along the "Belt and Road".

(3) Focus on the top design of dance culture. We will step up the strategic layout of opening up to the outside world, give play to the government's leading role in overall planning, strengthen cultural exchanges with the governments of countries and regions along the Belt and Road and establish a long-term cooperation mechanism. Explore the establishment of foreign dance culture industry fund, promote the effective allocation of cultural resources, rational flow of production factors, the depth of integration of cultural markets, the formation of the Silk Road ethnic dance culture and rational development of the industrial layout. On the basis of inheriting and innovating, "going global" in ethnic dance culture needs to continue with the reform and opening up and implement the overall strategy ${ }^{[7]}$. It is necessary to strengthen the top-level design of dance culture, clarify goals and objectives, implement institutions and entities, formulate guidelines and policies, work together in multiple ways and work together to promote the "going global" of outstanding ethnic dance culture.

(4) Pay attention to the combination of national aesthetic and human nature ${ }^{[8]}$. Due to the 
differences in living environment and cultural practices, each nation has a different aesthetic, ethnic dance contains a distinctive national aesthetic. National aesthetic makes national dance show different aesthetic effects, giving the audience a unique aesthetic enjoyment. In the diversified dance art forms of national dance, it is bound to stick to its own aesthetic characteristics and attract the attention of the audience. Human nature is different from other animal characteristics of mankind, improving human nature has always been the goal pursued by mankind. Praise and praise of human nature is the eternal theme of mankind, human nature is the best of human emotions. Outstanding ethnic dance culture, depending on the unity of national aesthetic and humanity beauty, the arrangement of the national dance works, we must consider the two aesthetic display and the combination of organic.

(5) Reform the training mode of college dance professionals. The strategy of "One Belt and One Road" has promoted cultural development. The social needs of dance professionals are constantly increasing, especially in the dance talents with comprehensive capabilities. Colleges and universities should be based on the needs of the market, accurate positioning dance professionals training objectives, to ensure the correct direction of personnel training to achieve the effective training of qualified personnel. Through dance education, students' comprehensive qualities are cultivated, and students are encouraged to perform dance appreciation, learn dance professional knowledge and enrich ethnic dance knowledge ${ }^{[9]}$. We should strengthen the practice ability cultivation of dance majors, set up practice teaching links reasonably, and carry out diversified dance practice teaching modes. Strengthen the construction of high quality dance courses in colleges and universities, make effective use of new technical means, enrich the curriculum resources and ensure the high quality and high standards of curriculum construction contents.

(6) To build a harmonious and inclusive global perspective. The "One Belt and One Road" strategy and its implementation plan have a distinctive "global perspective." Based on Asia and facing the world, at a time when the global economic situation is more complicated and the turning point of recovery has not yet emerged, this strategy will not only benefit Asia but also benefit the world. Culture should also have a global perspective and contain Chinese wisdom. Based on its long-term considerations, culture will always be open and inclusive, respect diverse, equal cooperation and harmonious development as the keynote of "going global" under the "Belt and Road" strategy. Let the development ideas of building, sharing and win-win cooperation go deep into the hearts of the people, mobilize the enthusiasm of all parties, establish common ideals of rejuvenating Eurasia, closely integrate culture with diplomacy and trade and economy, and form a coordinated development of cultural exchange, cultural communication and cultural trade.

(7) Enhance the competitiveness of cultural enterprises. Cultivating the main body of the cultural market with international competitiveness is a key link in promoting the national culture going global. Optimize the layout of cultural industries, give full play to their respective advantages in the eastern, central and western regions, strengthen the planning and construction of cultural industrial bases, develop cultural industrial clusters and enhance the scale, intensification and specialization of cultural industries. Promote the integration of culture and science and technology, thoroughly implement the strategy of promoting science and technology, speed up the use of high technology in the field of culture, enlarge and strengthen a batch of cultural and technological enterprises and bases and develop new forms of culture. Prosper the cultural market, innovate the business model, expand the popular culture consumer market and provide endogenous motivation for the development of the cultural industry ${ }^{[10]}$. We should focus on establishing a modern enterprise system, speed up the reform of business-oriented cultural units and promote the cultural industry to become a pillar industry in the national economy.

(8) Fully tap the characteristic ethnic dance resources. My country is vast and lives in 56 ethnic groups. During the long process of formation and integration of development, the masses of people of all nationalities jointly created and carried on the dance with distinctive local characteristics and ethnic style, and became the source of our country's traditional dance art. Mellow style, colorful ethnic folk dance, vividly expressed the people of all ethnic groups in our country and the aesthetic awareness and taste. Under the era of the "Belt and Road" strategy and culture going global, artists 
should, on the basis of extensively absorbing the national music and dance culture, form a rich and diverse dance system and create a group of ethnic groups with strong national characteristics and strong atmosphere of the times Dance art boutique, making it a show of the spirit of the times and reflects the national characteristics of the handed down for the national dance flourish.

\section{Conclusion}

To promote the outstanding national dance culture in the implementation of the "Belt and Road" strategy must rely on the support of the state policy and the layout of government agencies. It requires both deep-seated consideration at the macro level and reasonable operation at the practical and operational level. Scientific arrangement. In the process of "Belt and Road" strategy to promote the excellent national dance culture, we should draw lessons from the relevant experience of the traditional Chinese culture going abroad, combine with the characteristics of outstanding ethnic dance culture, propose innovative measures and promote them based on innovative measures Outstanding ethnic dance culture goes global, and at the same time it promotes the innovation of outstanding ethnic dance culture and achieves a virtuous circle. The research results of this paper, in theory, further enrich and complement the existing "One Belt, One Road" strategy and related theories of cultural communication. In practice, it can provide some scientific reference for decision-making of cultural departments.

\section{Acknowledgement}

This work is supported by social science fund project of Liaoning province (L17CMZ002): Innovation measures on promote the outstanding national dance culture going out under the "One Belt And One Road" strategy.

\section{References}

[1] Y. A. Gao, "'One Belt And One Road' strategy to promote the Chinese traditional culture 'going out'," Business Culture, vol. 23, no. 11, pp. 51-57, 2016.

[2] H. Zhou, "How Chinese culture better 'go out'," The People's Daily, 2015-01-22.

[3] J. X. Zhang, "The integration and development of cultural creativity and other industries," http://news.hexun.com/2014-11-26/170794867.html, 2018-1-2.

[4] T. J. Yang, "The construction of Chinese culture communication system under the background of One Belt and One Road.," People's Tribune, vol. 26, no. 22, pp. 140-141, 2017.

[5] J. Qin, H. B. Zhang, "'One Belt And One Road' is the national culture communication and identification in China." Journal of News Research, vol. 8, no. 9, pp. 6-8, 2017.

[6] D. X. Li, D. Wang, "The Development and Dissemination of Dance under the Influence of New Media," Journal of Weinan Normal University, vol. 32, no. 2, pp. 92-96, 2017.

[7] H. Zhou, "Strengthening the top level design to push the culture out," Dazhong Daily, 2015-10-14.

[8] J. J. Tong, "The National Aesthetic and the Beauty of Human Nature: Combination of Ethnic Dance Mass Communication Key," Guizhou Ethnic Studies, vol. 37, no. 6, pp. 94-97, 2016.

[9] Y. Y. Zhou, "The reform and analysis of the training mode of college dance professionals," Popular literature and art, vol. 61, no. 5, pp. 256-256, 2016.

[10] People's network, "Strengthening the overall strength and competitiveness of culture," http://theory.people.com.cn/n/2012/1214/c352852-19903212.html, 2018-1-2. 